\title{
Editorial
}

\section{Materials Research - Ibero-american Journal of Materials \\ Judicious, fair and educative!}

This issue of Materials Research contains 20 articles selected from those presented at the 59th Annual congress of ABM - Associação Brasileira de Metalurgia e Materiais, held in 2004, which celebrated the 60th birthday of the association. If one considers the history of similar associations in Latin America, this is a quite significant mark, since few technical societies have achieved such long period of existence. Along these many decades, ABM has definitely helped the development of Metallurgy in our country, through the annual congress and many other activities, such as courses, publications and thematic seminars, which have contributed to the formation of several generations of professionals. It is, therefore, with great pride that Materials Research rends tribute to one of its founding societies in this meaningful celebration.

The papers included in this issue followed the revision process of our journal and were selected, by the coordinators of the techni- cal sessions, among those originally submitted to the conference in English, in response to a call for the preparation of this special number of Materials Research.

The financial support from Departamento de Engenharia de Materiais, Universidade Federal de São Carlos - DEMa/UFSCar for mailing expenses; from Laboratório de Materiais Vítreos - LaMaV/ UFSCar for fax and telephone expenses as well as partial funding of the editorial assistant; from Núcleo de Informação Tecnológica - NIT/ UFSCar for the maintenance of our site are gratefully acknowledged. Associação Brasileira de Metalurgia e Materiais - ABM - has steadily provided for substantial part of the editorial assistant's salary. The secretaries of Associação Brasileira de Cerâmica - ABC, Associação Brasileira de Polímeros - ABPol, and ABM have helped advertising Materials Research as well with the management of its subscriptions and financial resources. 